\title{
Are Environmentally Innovative Companies Inclined towards Integrated Environmental Disclosure Policies?
}

\author{
Isabel-María García-Sánchez $^{1} \mathbb{D}$, Nicola Raimo ${ }^{2, * \mathbb{C}}$ and Filippo Vitolla ${ }^{2}$ \\ 1 Instituto Multidisciplinar de Empresa-IME, Campus Miguel de Unamuno, Universidad de Salamanca, \\ 37008 Salamanca, Spain; lajefa@usal.es \\ 2 Department of Management, Finance and Technology, LUM University, 70010 Casamassima, Italy; \\ vitolla@lum.it \\ * Correspondence: raimo@lum.it
}

check for updates

Citation: García-Sánchez, Isabel-María, Nicola Raimo, and

Filippo Vitolla. 2021. Are

Environmentally Innovative Companies Inclined towards Integrated Environmental Disclosure Policies?. Administrative Sciences 11: 29. https://doi.org/10.3390/ admsci11010029

Academic Editor: Ladislav Mura

Received: 16 February 2021

Accepted: 10 March 2021

Published: 15 March 2021

Publisher's Note: MDPI stays neutral with regard to jurisdictional claims in published maps and institutional affiliations.

Copyright: (c) 2021 by the authors. Licensee MDPI, Basel, Switzerland. This article is an open access article distributed under the terms and conditions of the Creative Commons Attribution (CC BY) license (https:// creativecommons.org/licenses/by/ $4.0 /)$.

\begin{abstract}
In recent years, the correct representation of environmental performance has become increasingly important. In light of this, in the academic field, numerous researchers have examined the level and quality of environmental disclosure. However, in the context of studies relating to the determinants of environmental disclosure, little attention has been paid to the role of environmental innovation. This study, in the context of voluntary disclosure theory, aims to fill this important gap through the analysis of the impact of environmental innovation on the level of integrated environmental information disclosed by companies and the analysis of environmental performance as a mediating factor in this relationship. The results show a positive relationship between environmental innovation and integrated environmental disclosure. In addition, they show that environmental performance represents a mediating factor in this relationship. However, complementary analyses show that responsible firms adopt silent strategies in their environmental integrated disclosure policies in order to limit the knowledge by external users of the different environmental actions implemented.
\end{abstract}

Keywords: environmental innovation; environmental performance; environmental disclosure; voluntary disclosure theory

\section{Introduction}

According to the Global Risks Report published by the World Economic World Economic Forum (2020), for the first time, the global risks that top the list, predicted in terms of probability, are all connected to the environment. These include extreme weather events; severe natural disasters; the failure of mitigation and adaptation to climate change; severe biodiversity losses and ecosystem collapse; environmental damage and man-made environmental disasters. Over the past decade, there have been numerous environmental disasters ranging from the explosion of the British Petroleum Oil Spill in the Gulf of Mexico to the nuclear accident at the Fukushima plant in Japan, to the recent Amazon forest fires. The causes of these environmental disasters are partly attributable to humans and are mainly related to overpopulation, pollution, industrialization, deforestation, global warming and climate change. These disasters are generating significant economic losses, which, according to the United Nations Office for Disaster Risk Reduction, in the last twenty years have increased by $151 \%$ compared to the previous twenty years.

The identification, assessment and management of environmental and climate issues are essential to ensure the creation of long-term value for firms (Rennie 2016; Ho et al. 2018; Vitolla et al. 2021a). However, in recent years, the correct representation of environmental aspects and performance has also become very important (Junior et al. 2017; Odoemelam and Okafor 2018; Raimo et al. 2019, 2020a, 2021a; Vitolla et al. 2019a). In fact, the growing concern about environmental and climatic disasters, often also deriving from business activities, has increased the information needs of public opinion on how firms manage 
environmental issues. Within the business arena, the level and quality of environmental disclosure is attracting the attention of governments, policymakers, shareholders, potential new investors and other categories of stakeholders (Jitmaneeroj 2016; Giannarakis et al. 2019; Salvi et al. 2020a, 2020b). The dissemination of environmental information therefore assumes significant importance for firms as it contributes to the sustainability of the business in the long term (Bennett and James 1998; Jitmaneeroj 2016), which is increasingly closely related to the satisfaction of the needs of direct and indirect stakeholders (Dyllick and Hockerts 2002; Vitolla and Raimo 2018; Vitolla et al. 2018).

The growing attention to environmental aspects has led to the development of standards and guidelines relating to environmental disclosure aimed at improving the level and quality of information disclosed by firms (Alazzani and Wan-Hussin 2013; Giannarakis et al. 2019). The introduction of standards and guidelines was reflected in the inclusion of environmental information by companies in different types of reports such as annual reports, environmental reports, social reports, sustainability reports and corporate social responsibility (CSR) reports.

These communication channels also represent those most examined by the academic literature on the topic of environmental disclosure (e.g., Cormier et al. 2005; Huang and Kung 2010; Kuo and Chen 2013; Baalouch et al. 2019). In this regard, numerous studies have examined the level and quality of environmental disclosure. However, despite the presence of various studies on the subject, knowledge about the determinants of environmental disclosure is still scarce and partly conflicting. In fact, past studies have suggested that some of the main drivers are firm size (e.g., O'Dwyer 2003; Cormier et al. 2005; Brammer and Pavelin 2008; Buniamin 2010), environmental sensitivity (e.g., O’Dwyer 2003; Brammer and Pavelin 2008; Vormedal and Ruud 2009; Buniamin 2010), ownership structure (e.g., Cormier et al. 2005; Rao et al. 2012), stakeholder pressure (e.g., Huang and Kung 2010), board characteristics (e.g., Rao et al. 2012; Trireksani and Djajadikerta 2016; Baalouch et al. 2019) and environmental performance (e.g., Al-Tuwaijri et al. 2004; Clarkson et al. 2008; Dawkins and Fraas 2011; Giannarakis et al. 2017). However, little attention has been paid to the role played by environmental innovation, and to date, there is a knowledge gap about the impact of environmental innovation on the level of information disclosed by companies (Radu and Francoeur 2017). In this regard, environmental innovation could play a primary role as a driver of environmental disclosure. In fact, innovative companies, in line with voluntary disclosure theory (Verrecchia 1983; Dye 1985), could have strong incentives to provide environmental information that gives a complete representation of their innovations and strategies and increases firm valuation (Radu and Francoeur 2017). However, despite the importance of the role of innovations, the academic literature presents very few contributions on the subject (Radu and Francoeur 2017; Fondevila et al. 2019).

This study aims to fill this important gap through the analysis of the impact of environmental innovation on the level of integrated environmental information disclosed by companies and the analysis of environmental performance as a mediating factor in this relationship. To this end, this study presents the following structure. Section 2 presents the background, theory and research hypotheses, while Section 3 introduces the methodology. Section 4 presents and discusses the results and, finally, Section 5 draws conclusions.

\section{Background, Theory and Research Hypotheses}

\subsection{Environmental Innovation and Environmental Disclosure}

Environmental innovation represents that particular type of innovation based on the pursuit of environmental efficiency (Scarpellini et al. 2012), connected to the search for greater competitiveness deriving from environmental improvement (Frondel et al. 2007, 2008; Del Río et al. 2010; Kemp and Oltra 2011; Cecere et al. 2014). It represents an important way for firms to satisfy consumer demands and comply with environmental regulations (Liao 2016). Different definitions of environmental innovation or eco-innovation have been proposed. A first important definition is that provided by the Eco-Innovation EcoInnovation Observatory (2016) according to which environmental innovation refers to the 
introduction of any new or significantly improved product, service, marketing or organizational change solution capable of reducing the use of natural resources and reducing the release of harmful substances during the entire production process (Skordoulis et al. 2020). Another definition is that provided by Kemp and Pontoglio (2011), according to which environmental innovation refers to the development of ecological, sustainable or renewable products and the reduction of environmental impacts through the use of technological solutions. Further, according to Blättel-Mink (1998), the introduction of ecological thinking into corporate strategy also represents a form of environmental innovation.

Therefore, environmental innovation can be observed both in environmental proactive firms that implement processes or develop innovative products (Garcés-Ayerbe et al. 2016) and in traditional innovative firms that adopt environmental criteria in the development of innovative solutions (Esty and Winston 2009; Albino et al. 2009).

The literature has examined the reasons that push companies to adopt innovative environmental solutions. In particular, some drivers may be represented by the willingness of companies to reduce risks and high environmental impacts (Kemp and Pearson 2007), to make the use of more efficient resources (Eco-Innovation Observatory 2016), to improve reputation (Chen 2008), to respond to market pressures (Oltra and Jean 2005), to increase supplier involvement (Hojnik and Ruzzier 2016), to mitigate social pressure and to obtain a competitive advantage (Forsman 2013; Qiu et al. 2020). Moreover, the CEO's reputation represents a factor that pushes a firm towards environmental innovation (Konadu et al. 2020).

Regarding its effects, environmental innovation, as a proactive strategy, is able to improve the performance of the company from both an environmental and a financial point of view (Porter and van der Linde 1995; Mirata and Emtairah 2005; Eiadat et al. 2008; Radu and Francoeur 2017). Indeed, through product and process innovation, firms are able to use resources more efficiently, eliminate unnecessary activities and materials and improve secondary treatment, with a consequent improvement in performance and creation of value for customers (Radu and Francoeur 2017). In this regard, environmental innovation could translate into energy and waste savings or reduction of materials resulting from the reuse of waste with beneficial effects on financial and environmental performance (Ambec and Lanoie 2008).

Environmental disclosure refers to the quantitative or qualitative information that measures, estimates or calculates the environmental impacts of companies (Burritt 2002). Environmental information can be provided in monetary or non-monetary terms through reports or corporate websites (Radu and Francoeur 2017). The academic literature has underlined the importance of reliable environmental disclosure (Nyquist 2003). It has also recorded a great variability in the levels, forms and quality of environmental information disseminated by companies (Radu and Francoeur 2017). A correct representation of environmental impacts can be considered a strategic choice for companies (Yin and Wang 2018). In fact, first of all, environmental disclosure can represent a tool to improve reputation, create a good corporate image (Huang and Chen 2015) and increase the involvement of stakeholders who are attentive to sustainability issues and concerned by environmental litigation risk and environmental policies (Yin and Wang 2018). Furthermore, environmental disclosure can represent a tool to convince stakeholders and potential investors of the company's ability to build or maintain a competitive advantage in the future (Herremans et al. 1993). In this regard, according to Epstein and Freedman (1994), many investors are interested in examining environmental disclosure to make investment decisions, favoring investments in highly transparent companies from an environmental point of view. In addition, according to the authors, for many investors, environmental management represents a more important element than the increase in dividends. Furthermore, environmental disclosure can represent a solution to attract a greater number of customers interested in environmental issues (Flammer 2013), through a correct representation of the most environmentally friendly products and production processes that are more oriented towards environmental protection (Yin and Wang 2018). 
The academic literature has often questioned the factors capable of influencing the level and quality of the environmental disclosure of companies, identifying different drivers connected, for example, to corporate governance and ownership structure (Cormier et al. 2005; Rao et al. 2012; Baalouch et al. 2019), environmental impact (O’Dwyer 2003; Brammer and Pavelin 2008; Vormedal and Ruud 2009; Buniamin 2010), firm size (O'Dwyer 2003; Cormier et al. 2005; Brammer and Pavelin 2008; Buniamin 2010), external pressures (Huang and Kung 2010) and environmental performance (Al-Tuwaijri et al. 2004; Clarkson et al. 2008; Dawkins and Fraas 2011; Giannarakis et al. 2017). However, the relationship between environmental innovation and environmental disclosure is still little explored. In this regard, Radu and Francoeur (2017) underlined that environmental innovation and environmental performance jointly determine environmental disclosure, while Fondevila et al. (2019), through a resource-based perspective, confirmed that eco-innovation represents a driver of environmental disclosure.

\subsection{Theory and Hypotheses Development}

In line with the voluntary disclosure theory (Verrecchia 1983; Dye 2001), this study examines the effect of environmental innovation on integrated environmental disclosure policies and analyzes the role of environmental performance as a mediating factor in this relationship. The research design is presented in Figure 1.

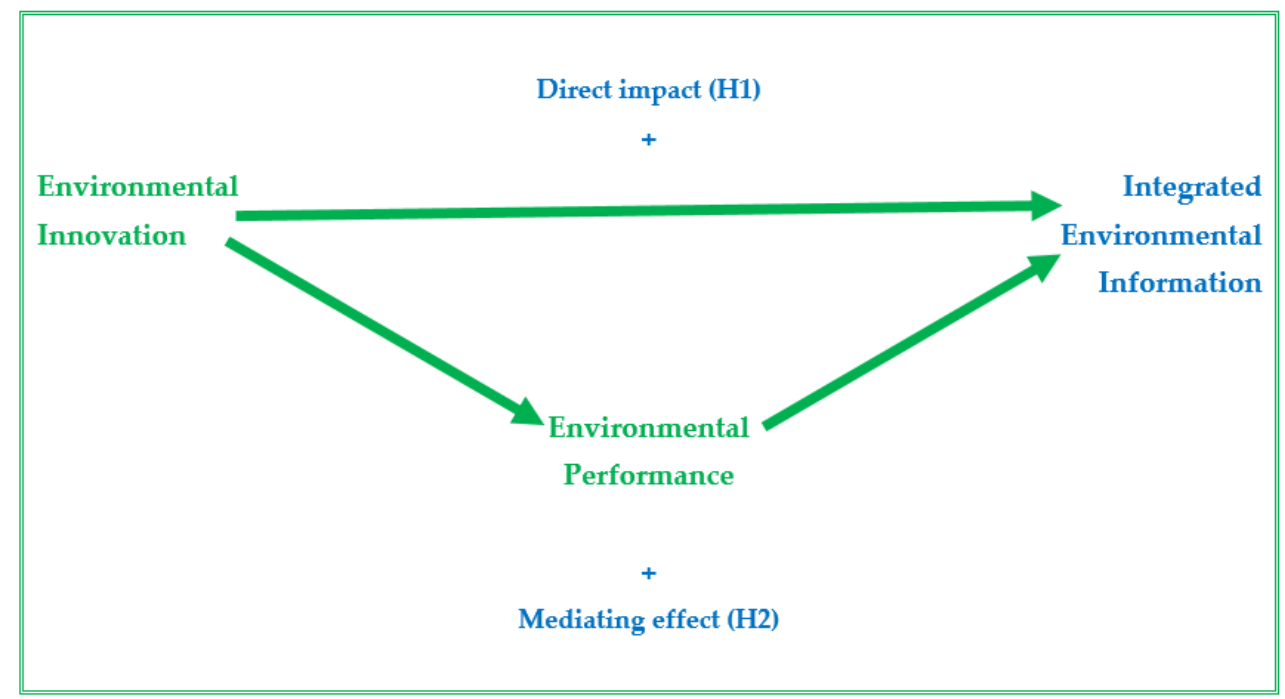

Figure 1. Research design.

According to this theory, there is a positive relationship between firm performance and voluntary disclosure (Dawkins and Fraas 2011). Specifically, according to the voluntary disclosure theory, companies with better performance will disclose more voluntary information to distinguish themselves from competitors and show the results obtained, while, on the contrary, companies with worse performance will disclose less voluntary information to avoid negative exposure (Vitolla et al. 2021b). More specifically, scholars interested in voluntary disclosure theory have highlighted a number of reasons why the best-performing companies are interested in providing more voluntary information (Dawkins and Fraas 2011). First, for these companies, the benefits of disclosure could outweigh the proprietary costs and the costs of collecting and representing information (Verrecchia 1983; Healy and Palepu 2001). Secondly, the best-performing companies could attract the approval of stakeholders by providing them with information on the results obtained (Dawkins and Fraas 2011). Furthermore, they may be interested in providing voluntary information in order to demonstrate their ability to maximize shareholder value (Singhvi and Desai 1971). Finally, the best-performing companies, by providing voluntary 
information, could promote a positive image and improve their reputation (Sharif and Rashid 2014).

Such circumstances could also relate to the dissemination of environmental information. In this regard, not only companies with better environmental performance (Li et al. 1997; Bewley and Li 2000) but also companies with a higher level of environmental innovation could be interested in disseminating a higher level of environmental information (Radu and Francoeur 2017). In fact, innovative companies from an environmental point of view can be considered as best performers because, thanks to their process and product innovations, they are able to use their resources more efficiently, identify and eliminate unnecessary activities and materials and improve the secondary treatment (Ambec and Lanoie 2008; Radu and Francoeur 2017). Therefore, according to voluntary disclosure theory, an innovative and proactive environmental strategy should push companies to provide more environmental information in order to show stakeholders their innovative capabilities, the strategy adopted and the results obtained. From an empirical point of view, Radu and Francoeur (2017) and Fondevila et al. (2019) found a positive effect of environmental innovation on the level of environmental disclosure. Therefore, in the light of this, it is possible to formulate the following hypothesis:

Hypothesis 1 (H1). Environmental innovation positively affects integrated environmental information.

In an attempt to open the black box involving the relationship between environmental innovation and integrated environmental disclosure, this study examines the mediating role of environmental performance.

Carrión-Flores and Innes (2010) found a bidirectional causal relationship between environmental innovation and environmental performance. In fact, environmental innovation increases the opportunities for companies to reduce environmental impacts and costs, resulting in better environmental and financial performance (Ambec and Lanoie 2008). In fact, it can promote clean production that reduces the environmental pollution of the entire production process (Long et al. 2017). In particular, empirical evidence suggests that environmental innovation reduces carbon emissions (Lee and Min 2015; Zhang et al. 2017) and consequently improves environmental performance (Lee and Min 2015; Long et al. 2017; Zhang et al. 2017). In addition Chiou et al. (2011) found that both green product innovation and green process innovation positively affect environmental performance.

Meanwhile, drawing on voluntary disclosure theory (Verrecchia 1983; Dye 2001), numerous studies have suggested a positive relationship between environmental performance and environmental disclosure. Bewley and Li (2000) and Li et al. (1997) found that companies with the best environmental performance have incentives to inform their stakeholders about their results through a wide voluntary environmental disclosure. From an empirical point of view, Luo and Tang (2014) found that environmental disclosure indicated the actual carbon performance, while Al-Tuwaijri et al. (2004) added that firms with good environmental performance tend to provide more environmental information. This result was also confirmed by Clarkson et al. (2008) and Giannarakis et al. (2017), according to which superior environmental performers tend to be more transparent in their environmental disclosure policies.

Taken together, we believe that environmental innovation can create a positive effect on environmental performance, which, in turn, exerts a positive impact on the integrated environmental disclosure. Therefore, in light of this, it is possible to formulate the following hypothesis:

Hypothesis 2 (H2). Environmental performance mediates the relationship between environmental innovation and integrated environmental information. 


\section{Methodology}

\subsection{Sample}

In order to test the research hypotheses established in the previous sections, the largest worldwide listed companies were considered as the target population. The selection of this population is consistent with the impact that their activities have on the environment and on the stock market (García-Sánchez et al. 2020c, 2020d), which leads to numerous stakeholders demanding integrated information regarding decisions regarding environmental activities (García-Sánchez et al. 2020a).

For this study, we used Thomson Reuters EIKON database, which combines economic, financial and other business data, including information for different CSR practices for more than 30,00 traded companies around the world (180 countries). However, based on the economic-financial information, as well as that related to corporate governance and sustainability available, the final sample used in the analysis corresponds to 5478 companies that operate in 10 industries, located in 68 different geographical areas. It configures an unbalanced panel of 44,095 observations for the 2009-2019 period. Table 1 shows the sample distribution, identifying a greater presence of companies located in the US, with economic activity framed in Basic Materials and Industry, a bias whose control requires the inclusion of different control variables at the sector and country level (García-Sánchez et al. 2020a).

Table 1. Sample.

\begin{tabular}{|c|c|c|c|}
\hline \multicolumn{4}{|c|}{ Panel A. Sample Distribution by Geographic Zone } \\
\hline Country & $\%$ & Country & $\%$ \\
\hline Argentina & 0.11 & Netherlands & 0.88 \\
\hline Australia & 6.59 & New Zealand & 0.55 \\
\hline Austria & 0.39 & Nigeria & 0.02 \\
\hline Bahrein & 0.05 & Norway & 0.48 \\
\hline Belgium & 0.67 & Oman & 0.08 \\
\hline Bermuda & 0.39 & Panama & 0.01 \\
\hline Brazil & 1.59 & Papua New Guinea & 0.02 \\
\hline Canada & 6.31 & Peru & 0.17 \\
\hline Cayman Islands & 0.04 & Philippines & 0.44 \\
\hline Chile & 0.50 & Poland & 0.55 \\
\hline China & 2.42 & Portugal & 0.27 \\
\hline Colombia & 0.24 & Puerto Rico & 0.01 \\
\hline Cyprus & 0.02 & Qatar & 0.15 \\
\hline Czech Republic & 0.08 & Russia & 0.72 \\
\hline Denmark & 0.63 & Saudi Arabia & 0.19 \\
\hline Egypt & 0.19 & Singapore & 1.16 \\
\hline Finland & 0.64 & South Africa & 2.08 \\
\hline France & 2.31 & Spain & 1.10 \\
\hline Germany & 2.03 & Sri Lanka & 0.02 \\
\hline Gibraltar & 0.02 & Sweden & 1.27 \\
\hline Greece & 0.40 & Switzerland & 1.66 \\
\hline Guernsey & 0.03 & Taiwan & 2.45 \\
\hline Hong Kong & 2.83 & Thailand & 0.58 \\
\hline Hungary & 0.08 & Turkey & 0.53 \\
\hline India & 1.64 & Ukraine & 0.01 \\
\hline Indonesia & 0.63 & United Arab Emirates & 0.16 \\
\hline Ireland & 0.62 & United Kingdom & 7.84 \\
\hline Isle Of Man & 0.01 & United States & 29.52 \\
\hline Israel & 0.32 & \multicolumn{2}{|c|}{ Panel B. Sample distribution by Industry } \\
\hline Italy & 1.21 & Industry & $\%$ \\
\hline Japan & 9.98 & Oil and Gas & 6.99 \\
\hline Jersey & 0.07 & Basic Materials & 9.98 \\
\hline Jordan & 0.02 & Industry & 18.22 \\
\hline Korea (South) & 2.10 & Consumer goods & 10.52 \\
\hline Kuwait & 0.13 & Health & 6.02 \\
\hline Luxemburg & 0.15 & Consumer services & 12.95 \\
\hline Macau & 0.03 & Telecommunications & 2.65 \\
\hline Malaysia & 0.92 & Public services & 4.53 \\
\hline Mexico & 0.62 & Financial and Real Estate & 21.37 \\
\hline Morocco & 0.07 & Technology & 6.77 \\
\hline
\end{tabular}




\subsection{Empirical Models}

The proposed hypotheses were tested using the empirical models reflected in Equations (1) and (2). The first equation is formulated to analyze the impact that environmental innovation (EnvInno) has on environmental performance (EnvPerf), which will act as a mediating factor in the second equation. In this model, both variables are introduced as explanatory factors of the corporate decision to disclose integrated environmental information (EnvI.Inf).

$$
\begin{aligned}
& \text { EnvPerf }_{i t}=\beta_{0}+\beta_{1} \text { EnvInno }_{\text {it }}+\sum_{\mathrm{j}=2}^{12} \beta_{\mathrm{j}} \text { Firm }_{\mathrm{it}}+\sum_{\mathrm{k}=13}^{17} \beta_{\mathrm{k}} \text { Board }_{\mathrm{t}}+\sum_{\mathrm{l}=18}^{24} \beta_{1} \text { Institutional }_{\mathrm{t}}+\beta_{25} \text { Zone }+ \\
& \beta_{26} \text { Industry }+\beta_{27} \text { Year }+\mu_{i t}+\eta_{i}
\end{aligned}
$$

$$
\begin{gathered}
\text { EnvI.Inf }_{\mathrm{it}}=\boldsymbol{z}_{0}+\boldsymbol{\delta}_{1} \text { EnvInno }_{\mathrm{it}}+\boldsymbol{z}_{2} \text { EnvPerf }_{\mathrm{it}}+\sum_{\mathrm{j}=3}^{13} \beta_{\mathrm{j}} \text { Firm }_{\mathrm{it}}+\sum_{\mathrm{k}=14}^{18} \beta_{\mathrm{k}} \text { Board }_{\mathrm{t}}+\sum_{\mathrm{l}=19}^{25} \beta_{\mathrm{l}} \text { Institutional }_{\mathrm{t}}+ \\
\beta_{26} \text { Zone }+\beta_{27} \text { Industry }+\beta_{28} \text { Year }+\mu_{\mathrm{it}}+\eta_{\mathrm{i}}
\end{gathered}
$$

$\beta$ and $\zeta$ are the estimated parameters. The company is referred to by $I$, and the time period is represented by $t$. The models include $\eta$, which represents the unobservable heterogeneity and $\mu_{\mathrm{it}}$, the disturbance term. Lagged independent variables are used to avoid endogeneity problems. Zone, Industry and Year are included to control for variation across country, industry and time.

The dependent variable EnvI.Inf corresponds to an ordinal variable that takes values between 0 and 4, depending on whether (i) the report of the company is openly revealing about the environmental challenges, opportunities, dilemmas and trade-offs it faces in an integrated way; (ii) the company's report takes into account the global activities of the company; (iii) the company's report incorporates the different Global Reporting Initiative (GRI) environmental indicators; and (iv) the company's report on crisis management systems or reputation disaster aand recovery plans to reduce or minimize the effects of environmental reputation disasters.

The EnvInno variable, following Frías-Aceituno and Aibar-Gúzman (2021), is an ordinal variable that takes values between 0 and 3 to identify whether companies have invested in environmental innovation projects related to (i) the use of clean technologies; (ii) ecological processes in the design and manufacture of products; and (iii) manufacturing and marketing of environmentally responsible products. The EnvPerf variable is formed from the environmental score from Thomson Reuters.

On the other hand, in order to avoid biased results, following authors such as FríasAceituno et al. (2013a, 2013b, 2014), García-Sánchez and Noguera-Gámez (2017a, 2017b, 2018), García-Sánchez et al. (2013, 2019, 2021), Vitolla et al. (2019b, 2019c, 2020a, 2020b) and Raimo et al. (2020a, 2020b, 2020c, 2021b), we included control variables that determine those firm characteristics, the board of directors and the institutional environment that influence the different corporate decisions (see Table 2). Regarding the firms' characteristics, the variables are related to size (F_Size), age (F_Age), profitability (ROA), indebtedness (Leverage), growth opportunities (Growth), dividend policy (Divid), working capital (WorCap), internationalization (F_Intern), problems of finance access (KZIndex), analysts that cover the companies (Analysts) and errors in the prediction of these financial agents (Error). Corporate governance variables correspond with the power of the CEO (CPI), the size (B_Size) and activity (B_Activity) of the board of directors, its diversity (B_Women) and the presence of a financial expert on the audit committee (AC_Exp). Institutional variables are related to a civil legal system (Civil_Law), the existence of different norms that regulate obligations in matters of corporate (TranspIndex and Mandatory) and environmental transparency (ERRI), as well as the strength of the judicial system (LOIndex and JEIndex) and the mimetic isomorphism at the industrial level (ICSRPI).

The firm's characteristics associated with size, profitability and indebtedness allow us to identify the level of visibility of the company, which implies the existence of a greater interest in the environmental strategy and performance of the firms by different interest groups (García-Sánchez et al. 2020a). Additionally, companies that have higher levels of working capital and with policies aimed at the distribution of higher dividends 
show a greater interest in disclosing social and environmental information associated with more sustainable behaviors (García-Sánchez et al. 2020e). On the other hand, longer-lived companies, due to their experience and interest in maintaining the status they enjoy, are usually more likely to adopt new reporting models and disclose higher quality information (Vitolla et al. 2019c). The opportunities for growth and the degree of internationalization of the company may or may not favor the disclosure of integrated information depending on the proprietary costs perceived by the company's executives and their power within these companies (García-Sánchez et al. 2020a).

Table 2. Variables and descriptive statistics.

\begin{tabular}{|c|c|c|c|}
\hline Variable & Measure & Relative Frequency & \\
\hline AC_Exp & Dummy if a financial expert is on the audit committee & 0.49 & \\
\hline Civil_Law & Dummy if the firm is located in a civil law country & 0.38 & \\
\hline \multirow[t]{2}{*}{ Mandatory } & Dummy if the firm is located in South Africa & 0.02 & \\
\hline & & Mean & Std.Dev \\
\hline EnvI.Inf & Integrated level of environmental information ( $0-4$ points) & 1.21 & 1.16 \\
\hline EnvInno & Environmental innovation projects ( $0-3$ values) & 0.6 & 0.89 \\
\hline EnvPerf & Environmental performance score & 49.64 & 31.97 \\
\hline F_Size & Logarithm of total assets by firm size measure & 16.69 & 2.82 \\
\hline F_Age & Age of the company since its establishment & 37.39 & 31.86 \\
\hline $\mathrm{ROA}$ & Ratio Return on Assets & 4.85 & 15.19 \\
\hline Growth & Sales mean value in the last five years & 2.97 & 0.32 \\
\hline Error & Forecast error (Martínez-Ferrero et al. 2016) & 0.09 & 1.54 \\
\hline KZIndex & KZ index of Kaplan and Zingales (1997) & 0.01 & 0.08 \\
\hline Leverage & Ratio Total Debt to Total Equity & 0.14 & 0.17 \\
\hline WorCap & Working capital & 0.92 & 0.01 \\
\hline Divid & Dividends paid by the company & 61.89 & 74.44 \\
\hline F_Intern & Investment in total assets in other countries & 17.68 & 26.82 \\
\hline Analysts & Analysts follow the company & 13.09 & 8.98 \\
\hline CPI & CEO Power Index (García-Sánchez et al. 2020a) & 1.92 & 0.73 \\
\hline B_Size & Number of directors on the board & 10.07 & 3.53 \\
\hline B_Activity & Annual meetings of the board & 18.41 & 10.87 \\
\hline B_Women & Percentage of female directors on the board & 0.12 & 0.11 \\
\hline IENVPI & Industry Environmental Index (Amor-Esteban et al. 2018, 2019) & 0.02 & 0.91 \\
\hline ERRI & National environmental regulations index (Esty and Porter 2001) & 0.93 & 0.64 \\
\hline TranspIndex & Disclosure legal requirement at country level & 0.56 & 0.82 \\
\hline LOIndex & The index of law and order from La La Porta et al. (1998) & 8.89 & 1.68 \\
\hline JEIndex & The index of judicial efficiency from La La Porta et al. (1998) & 9.18 & 1.55 \\
\hline
\end{tabular}

In relation to corporate governance, good governance practices associated with the presence of financial experts in the audit committee, size, activity and diversity of the board of directors favor corporate transparency with the aim that investors and other stakeholders have the information necessary in their decision-making (Amorelli and García-Sánchez 2020). On the contrary, the accumulation in the status of the CEO negatively affects the dissemination of integrated information (García-Sánchez et al. 2020a) but is essential to promote environmental innovation (Frías-Aceituno and Aibar-Gúzman 2021).

Institutional pressures at the country level, according to Frías-Aceituno et al. (2013b) and Vitolla et al. (2020c), are controlled by variables including those that identify a legal tradition of civil law that protects the interests of other stakeholders in addition to investors and the legal application framework proposed by La Porta et al. (1998) relative to the judicial efficiency index and the law and order index. Variables that identify the legal requirements regarding transparency in each country are also included, specifically controlling the case of South Africa because in this country, it has been mandatory since 2010 to present an integrated report in accordance with the IIRC recommendations. In addition, the industry pressures are considered in order to control the mimetic isomorphism identified in the previous paper relating to environmental issues (Amor-Esteban et al. 2018, 2019).

The analysis techniques used correspond to ordinary and linear regressions for panel data due to the nature of the dependent variables, EnvI.Inf and EnvPerf. Specifically, in the first model, Equation (1), given the continuous numerical nature of the EnvPerf variable, 
a line regression is used; while the second model, Equation (2) is estimated through an ordinal regression because the EnvI.Inf variable takes values between 0 and 4 and there is an order between these values.

\section{Results and Discussion}

\subsection{Descriptive Statistics}

Table 2 shows the descriptive statistics of the variables proposed for the empirical analysis. It can be observed that on average, the companies obtain a score of 1.21 out of the 4 possible points that they can achieve in the indicator. Although there is a variability of 1.16, indicating that there are companies whose corporate transparency practices are close to 3 , and a limited number of companies would meet the four weighted integrated transparency criteria. In relation to environmental innovation, companies have implemented between one and two environmental innovations, obtaining a score of $49.64(+31.97)$ points out of 100 in their environmental performance.

Table 3 shows the correlations between the different variables, not detecting multicollinearity problems.

Table 3. Bivariate correlations ${ }^{* * *} p<0.01,{ }^{* *} p<0.05,{ }^{*} p<0.1$ ).

\begin{tabular}{|c|c|c|c|c|c|c|c|c|c|}
\hline & & 1 & 2 & 3 & 4 & 5 & 6 & 7 & 8 \\
\hline 1 & EnvI.Inf & 1 & & & & & & & \\
\hline 2 & EnvInno & $0.40^{* * *}$ & 1 & & & & & & \\
\hline 3 & EnvPerf & $0.50^{* * *}$ & $0.29^{* * *}$ & 1 & & & & & \\
\hline 4 & F_Size & $0.30^{* * *}$ & $0.28^{* * *}$ & $0.18^{* * *}$ & 1 & & & & \\
\hline 5 & F_Age & $0.20^{* * *}$ & $0.23^{* * *}$ & $0.13^{* * *}$ & $0.18^{* * *}$ & 1 & & & \\
\hline 6 & ROA & $0.03^{* * *}$ & 0.00 & $0.02 * * *$ & $0.04^{* * *}$ & $0.04^{* * *}$ & 1 & & \\
\hline 7 & Growth & 0.00 & 0.00 & 0.01 & 0.00 & $-0.01 *$ & 0.00 & 1 & \\
\hline 8 & Error & $-0.02^{* * *}$ & $-0.01 * *$ & $-0.01 *$ & $-0.03^{* * *}$ & $-0.02^{* * *}$ & $-0.10^{* * *}$ & 0.00 & 1 \\
\hline 9 & KZIndex & $0.07^{* * *}$ & $0.07^{* * *}$ & $0.03^{* * *}$ & $0.34^{* * *}$ & $0.02^{* * *}$ & -0.01 & 0.00 & 0.00 \\
\hline 10 & Leverage & 0.00 & 0.00 & 0.00 & 0.00 & 0.00 & -0.01 & 0.00 & $0.42 * * *$ \\
\hline 11 & WorCap & $0.04^{* * *}$ & $0.03^{* * *}$ & $0.02 * * *$ & $0.18^{* * *}$ & 0.01 & $0.02^{* * *}$ & 0.00 & -0.01 \\
\hline 12 & Divid & -0.01 & $0.01^{* * *}$ & $0.01 *$ & $0.15^{* * *}$ & $-0.01 *$ & 0.00 & 0.00 & 0.00 \\
\hline 13 & F_Intern & $0.14^{* * *}$ & $0.08^{* * *}$ & $0.07^{* * *}$ & $-0.03^{* * *}$ & $0.06^{* * *}$ & $0.01 *$ & 0.00 & 0.00 \\
\hline 14 & Analysts & $0.30^{* * *}$ & $0.21^{* * *}$ & $0.17^{* * *}$ & $0.24^{* * *}$ & $0.05^{* * *}$ & $0.09^{* * *}$ & $-0.01 *$ & -0.01 \\
\hline 15 & CPI & $0.04^{* * *}$ & -0.01 & $0.02 * * *$ & $0.10^{* * *}$ & $-0.02 * *$ & $-0.01^{* *}$ & 0.01 & -0.01 \\
\hline 16 & B_Size & $0.21^{* * *}$ & $0.10 * * *$ & $0.29 * * *$ & $0.19 * * *$ & $0.08 * * *$ & $0.02 * * *$ & $0.02 * * *$ & $-0.02 * * *$ \\
\hline 17 & B_Activity & $0.14^{* * *}$ & $0.03 * * *$ & $0.15^{* * *}$ & $0.04 * * *$ & $0.03^{* * *}$ & -0.01 & 0.00 & $-0.02 * * *$ \\
\hline 18 & B_Women & $0.12^{* * *}$ & $0.02^{* * *}$ & $0.15^{* * *}$ & $-0.13^{* * *}$ & $0.04^{* * *}$ & $0.02^{* * *}$ & -0.01 & -0.01 \\
\hline 19 & $\overline{A C} \_$Exp & $0.08^{* * *}$ & $-0.02 * * *$ & $-0.07^{* * *}$ & $-0.13^{* * *}$ & $-0.02 * * *$ & 0.00 & 0.01 & 0.00 \\
\hline 20 & IENVPI & $0.13^{* * *}$ & $0.20 * * *$ & $0.09 * * *$ & $-0.04^{* * *}$ & $0.07^{* * *}$ & $-0.03^{* * *}$ & 0.00 & 0.00 \\
\hline 21 & ERRI & $-0.08^{* * *}$ & $0.05^{* * *}$ & $0.03^{* * *}$ & $-0.41^{* * *}$ & $0.03^{* * *}$ & $-0.05 * * *$ & 0.00 & 0.01 \\
\hline 22 & Civil_Law & $0.20^{* * *}$ & $0.24^{* * *}$ & $0.15^{* * *}$ & $0.53 * * *$ & $0.10^{* * *}$ & $0.01 *$ & $0.01 * *$ & $-0.02 * * *$ \\
\hline 23 & TranspIndex & $0.10^{* * *}$ & $-0.03^{* * *}$ & $0.03^{* * *}$ & $-0.35^{* * *}$ & 0.00 & $-0.01^{* * *}$ & 0.01 & $-0.01 *$ \\
\hline 24 & LOIndex & $-0.19^{* * *}$ & $-0.03^{* * *}$ & $-0.05^{* * *}$ & $-0.44^{* * *}$ & $-0.05^{* * *}$ & $-0.08 * * *$ & 0.00 & $0.01 * * *$ \\
\hline 25 & JEIndex & $-0.17^{* * *}$ & $-0.04^{* * *}$ & $-0.04^{* * *}$ & $-0.34^{* * *}$ & $-0.03^{* * *}$ & $-0.05^{* * *}$ & 0.00 & 0.00 \\
\hline \multirow[t]{2}{*}{26} & Mandatory & $0.13^{* * *}$ & $-0.04^{* * *}$ & 0.00 & 0.01 & $0.04^{* * *}$ & $0.03^{* * *}$ & 0.00 & 0.00 \\
\hline & & 9 & 10 & 11 & 12 & 13 & 14 & 15 & 16 \\
\hline 9 & KZIndex & 1 & & & & & & & \\
\hline 10 & Leverage & 0.01 & 1 & & & & & & \\
\hline 11 & WorCap & $0.26^{* * *}$ & 0.00 & 1 & & & & & \\
\hline 12 & Divid & $0.22 * * *$ & 0.00 & $0.13^{* * *}$ & 1 & & & & \\
\hline 13 & F_Intern & $-0.02^{* * *}$ & -0.01 & $-0.03^{* * *}$ & $-0.03^{* * *}$ & 1 & & & \\
\hline 14 & Analysts & $0.05^{* * *}$ & -0.01 & $0.07 * * *$ & $0.01 * * *$ & $0.08^{* * *}$ & 1 & & \\
\hline 15 & CPI & $0.03^{* * *}$ & 0.00 & $0.02 * * *$ & $0.01^{* *}$ & $0.01^{* *}$ & $-0.06^{* * *}$ & 1 & \\
\hline 16 & B_Size & 0.00 & 0.01 & 0.00 & $-0.03^{* * *}$ & $0.03^{* * *}$ & $0.12 * * *$ & $0.05^{* * *}$ & 1 \\
\hline 17 & B_Activity & $0.02 * *$ & 0.00 & 0.00 & 0.01 & $0.08^{* * *}$ & $-0.04^{* * *}$ & $0.33^{* * *}$ & $-0.10^{* * *}$ \\
\hline 18 & B_Women & $-0.07^{* * *}$ & $0.01 * *$ & $-0.03^{* * *}$ & $-0.05^{* * *}$ & $-0.02 * * *$ & $0.05^{* * *}$ & $-0.16^{* * *}$ & $0.08^{* * *}$ \\
\hline 19 & AC_Exp & $-0.05^{* * *}$ & 0.00 & $-0.03 * * *$ & $-0.04^{* * *}$ & 0.00 & $0.04^{* * *}$ & $-0.19 * * *$ & $0.02 * * *$ \\
\hline 20 & IENVPI & $0.05^{* * *}$ & $-0.01^{* *}$ & $0.02 * * *$ & $-0.01 *$ & $0.16^{* * *}$ & $-0.05^{* * *}$ & $0.02 * * *$ & $-0.02^{* * *}$ \\
\hline 21 & ERRI & $-0.20^{* * *}$ & 0.00 & $-0.12^{* * *}$ & $-0.08^{* * *}$ & $0.13^{* * *}$ & 0.00 & $-0.15^{* * *}$ & $-0.06^{* * *}$ \\
\hline 22 & Civil_Law & $0.15^{* * *}$ & 0.00 & $0.08^{* * *}$ & $0.10^{* * *}$ & $0.05^{* * *}$ & $0.02 * * *$ & $0.11^{* * *}$ & $0.12^{* * *}$ \\
\hline 23 & TranspIndex & $-0.08^{* * *}$ & -0.01 & $-0.04^{* * *}$ & $-0.05^{* * *}$ & $0.23 * * *$ & $-0.06^{* * *}$ & $0.09 * * *$ & $-0.07^{* * *}$ \\
\hline 24 & LOIndex & $-0.25^{* * *}$ & 0.00 & $-0.14^{* * *}$ & $-0.10^{* * *}$ & $0.01^{* *}$ & $-0.02 * * *$ & $-0.17^{* * *}$ & $-0.07^{* * *}$ \\
\hline 25 & JEIndex & $-0.26^{* * *}$ & -0.01 & $-0.16^{* * *}$ & $-0.08^{* * *}$ & $0.02 * * *$ & $-0.03 * * *$ & $-0.11^{* * *}$ & $-0.09 * * *$ \\
\hline 26 & Mandatory & $-0.02^{* * *}$ & 0.01 & $-0.01 *$ & $-0.01^{* * *}$ & 0.00 & $-0.11^{* * *}$ & $0.05^{* * *}$ & $0.01^{* *}$ \\
\hline
\end{tabular}


Table 3. Cont.

\begin{tabular}{|c|c|c|c|c|c|c|c|c|c|c|}
\hline & & 17 & 18 & 19 & 20 & 21 & 22 & 23 & 24 & 25 \\
\hline 17 & B_Activity & 1 & & & & & & & & \\
\hline 18 & B_Women & -0.01 & 1 & & & & & & & \\
\hline 19 & AC_Exp & $-0.12^{* * *}$ & $0.28^{* * *}$ & 1 & & & & & & \\
\hline 20 & IENVPI & $0.06^{* * *}$ & $-0.06^{* * *}$ & $-0.02^{* * *}$ & 1 & & & & & \\
\hline 21 & ERRI & $-0.07^{* * *}$ & $0.11^{* * *}$ & $0.04^{* * *}$ & $-0.05^{* * *}$ & 1 & & & & \\
\hline 22 & Civil_Law & $0.11^{* * *}$ & $-0.13^{* * *}$ & $-0.19 * * *$ & $0.05^{* * *}$ & $-0.21^{* * *}$ & 1 & & & \\
\hline 23 & TranspIndex & $0.24 * * *$ & $0.11^{* * *}$ & $0.05^{* * *}$ & $0.05^{* * *}$ & $0.28^{* * *}$ & $-0.04^{* * *}$ & 1 & & \\
\hline 24 & LOIndex & $-0.11^{* * *}$ & $0.09 * * *$ & $0.06^{* * *}$ & $-0.02 * * *$ & $0.87^{* * *}$ & $-0.28^{* * *}$ & $0.16^{* * *}$ & 1 & \\
\hline 25 & JEIndex & $-0.08^{* * *}$ & $0.05^{* * *}$ & $0.07^{* * *}$ & $-0.03^{* * *}$ & $0.75^{* * *}$ & $-0.42 * * *$ & $0.12^{* * *}$ & $0.77^{* * *}$ & 1 \\
\hline 26 & Mandatory & $0.04^{* * *}$ & $0.05^{* * *}$ & $0.04 * * *$ & -0.01 & $-0.22 * * *$ & $-0.11^{* * *}$ & $-0.10 * * *$ & $-0.39 * * *$ & $-0.30^{* * *}$ \\
\hline
\end{tabular}

\subsection{Basic Model Results}

Table 4 summarizes the results of the estimates of Equations (1) and (2). Observing the second column of the table, the results obtained for Equation (1) show that environmental innovation (EnvInno: coeff. $=0.361 ; p$-value $=0.000$ ) has a positive effect, significant from an econometric point of view, on the corporate decision to disclose integrated information on the companies' environmental strategy, activities and risks. These results allow us to accept the proposed Hypothesis H1.

We also observe that the representative variable of environmental performance shows the same behavior as innovation, although the effect is smaller (EnvPerf: coeff. $=0.00584$; $p$-value $=0.000$ ).

In turn, in the first column of Table 4 in which the results for Equation (2) are reflected, it can be seen that the representative variable of environmental innovation has a positive, statistically significant effect on the environmental performance of the companies (EnvInno: coeff. $=2.385 ; p$-value $=0.021)$. This impact, together with the one that the EnvPerf variable has on EnvI.Inf in Equation (1), allows us to accept the research hypothesis $\mathrm{H} 2$ regarding the existence of a mediating effect.

The theoretical basis for explaining these results is represented by voluntary disclosure theory. The most innovative companies from the environmental point of view are in fact interested in providing integrated environmental information in order to show their environmental technologies, their strategies and the results obtained (García-Sánchez et al. 2020f). In particular, these companies are interested in showing the ability to use resources efficiently, to improve secondary treatment and to eliminate unnecessary materials and activities. These circumstances explain the positive effect of environmental innovation on integrated environmental information. This result is in line with the findings of Radu and Francoeur (2017) and Fondevila et al. (2019) according to which environmental innovation represents a driver of environmental disclosure. In particular, our results extend those obtained from previous studies, demonstrating that environmental innovation pushes companies to provide environmental information in an integrated manner.

In addition, the efficient use of resources, the ability to improve secondary treatment and eliminate unnecessary materials and activities obtained by companies thanks to environmental innovations also improve environmental performance as they reduce environmental impacts. In turn, the best environmental performance, in line with voluntary disclosure theory, pushes companies to provide integrated environmental information. In fact, the best environmentally performing companies are interested in disseminating information to make it known to the stakeholders and, consequently, to obtain consent and improve their reputation. These circumstances explain the mediating role of environmental performance in the relationship between environmental innovation and integrated environmental information. This result extends the findings of previous studies that examined the relationship between environmental innovation and environmental disclosure without including mediating variables. 
Table 4. Dependence models $\left({ }^{* * *} p<0.01,{ }^{* *} p<0.05,{ }^{*} p<0.1\right)$.

\begin{tabular}{|c|c|c|c|c|}
\hline & Equation (2) & Equation (1) & Robust 1 & Robust 2 \\
\hline & EnvPerf & EnvI.Inf & EnvI.Inf1 & EnvI.Inf2 \\
\hline & $\begin{array}{c}\text { Coeff. } \\
\text { (Std. Error) }\end{array}$ & $\begin{array}{c}\text { Coeff. } \\
\text { (Std. Error) }\end{array}$ & $\begin{array}{c}\text { Coeff. } \\
\text { (Std. Error) }\end{array}$ & $\begin{array}{c}\text { Coeff. } \\
\text { (Std. Error) }\end{array}$ \\
\hline EnvInno & $\begin{array}{c}2.385 * * \\
-1.035\end{array}$ & $\begin{array}{l}0.361 * * * \\
(0.0318)\end{array}$ & $\begin{array}{l}0.556^{* * *} \\
(0.0510)\end{array}$ & $\begin{array}{l}0.189 * * * \\
(0.0319)\end{array}$ \\
\hline EnvPerf & & $\begin{array}{l}0.00584^{* * *} \\
(0.000711)\end{array}$ & $\begin{array}{c}0.00625^{* * * *} \\
(0.00111)\end{array}$ & $\begin{array}{l}0.00569 * * * \\
(0.000754)\end{array}$ \\
\hline F_Size & $\begin{array}{l}3.117^{*} \\
-1.696\end{array}$ & $\begin{array}{l}0.359 * * * \\
(0.0255)\end{array}$ & $\begin{array}{l}0.680^{* * *} \\
(0.0484)\end{array}$ & $\begin{array}{l}0.203^{* * *} \\
(0.0232)\end{array}$ \\
\hline F_Age & $\begin{array}{c}1.764^{* * *} \\
(0.225)\end{array}$ & $\begin{array}{c}0.00630^{* * *} \\
(0.00121)\end{array}$ & $\begin{array}{l}0.0137^{* * *} \\
(0.00219)\end{array}$ & $\begin{array}{l}0.00242 * * \\
(0.00107)\end{array}$ \\
\hline ROA & $\begin{array}{l}-0.0392 \\
(0.0547)\end{array}$ & $\begin{array}{c}0.00591^{* * *} \\
(0.00206)\end{array}$ & $\begin{array}{l}0.0126^{* * * *} \\
(0.00363)\end{array}$ & $\begin{array}{c}0.00303 \\
(0.00206)\end{array}$ \\
\hline Growth & $\begin{array}{l}-0.0776 \\
(0.0566)\end{array}$ & $\begin{array}{l}-0.00265 \\
(0.00305)\end{array}$ & $\begin{array}{l}-0.167 * \\
(0.0961)\end{array}$ & $\begin{array}{l}-0.00155 \\
(0.00251)\end{array}$ \\
\hline Error & $\begin{array}{l}-0.183 \\
(0.374)\end{array}$ & $\begin{array}{c}-0.00717 \\
(0.0182)\end{array}$ & $\begin{array}{c}0.0152 \\
(0.0290)\end{array}$ & $\begin{array}{l}-0.0151 \\
(0.0198)\end{array}$ \\
\hline KZIndex & $\begin{array}{l}-35.82 \\
(59.31)\end{array}$ & $\begin{array}{c}-5.001 * * * \\
-1.020\end{array}$ & $\begin{array}{c}-9.378^{* * *} \\
-1.701\end{array}$ & $\begin{array}{l}-2.112^{* *} \\
(0.934)\end{array}$ \\
\hline Leverage & $\begin{array}{c}0.000239 \\
(0.000197)\end{array}$ & $\begin{array}{c}7.66 e-06 \\
(9.99 e-06)\end{array}$ & $\begin{array}{c}3.11 \mathrm{e}-06 \\
(1.51 \mathrm{e}-05)\end{array}$ & $\begin{array}{c}6.67 \mathrm{e}-06 \\
(1.09 \mathrm{e}-05)\end{array}$ \\
\hline WorCap & $\begin{array}{c}2.93 e-09 * * \\
(1.17 e-09)\end{array}$ & $\begin{array}{c}-1.15 \mathrm{e}-09^{* * *} \\
(2.78 \mathrm{e}-10)\end{array}$ & $\begin{array}{c}-2.20 \mathrm{e}-09^{* * *} \\
(4.59 \mathrm{e}-10)\end{array}$ & $\begin{array}{l}-3.63 e-10 \\
(2.55 e-10)\end{array}$ \\
\hline Divid & $\begin{array}{l}-0.0380 \\
(0.0250)\end{array}$ & $\begin{array}{l}-0.000200 \\
(0.000153)\end{array}$ & $\begin{array}{l}-0.000191 \\
(0.000296)\end{array}$ & $\begin{array}{l}-0.000211 \\
(0.000135)\end{array}$ \\
\hline F_Intern & $\begin{array}{c}0.0146 \\
(0.0345)\end{array}$ & $\begin{array}{l}0.000671 \\
(0.00114)\end{array}$ & $\begin{array}{l}0.00313 * \\
(0.00180)\end{array}$ & $\begin{array}{c}-0.000757 \\
(0.00113)\end{array}$ \\
\hline Analysts & $\begin{array}{c}0.164 \\
(0.140)\end{array}$ & $\begin{array}{l}0.0475^{* * *} \\
(0.00395)\end{array}$ & $\begin{array}{l}0.0682^{* * * *} \\
(0.00658)\end{array}$ & $\begin{array}{l}0.0268^{* * *} \\
(0.00379)\end{array}$ \\
\hline CPI & $\begin{array}{c}-1.471 \text { ** } \\
(0.730)\end{array}$ & $\begin{array}{c}-0.0762 * * * \\
(0.0293)\end{array}$ & $\begin{array}{l}-0.111^{* * *} \\
(0.0458)\end{array}$ & $\begin{array}{l}-0.0477 \\
(0.0310)\end{array}$ \\
\hline B_Size & $\begin{array}{l}0.0164 \\
(0.170)\end{array}$ & $\begin{array}{c}0.00444 \\
(0.00738)\end{array}$ & $\begin{array}{c}-0.00682 \\
(0.0116)\end{array}$ & $\begin{array}{c}0.00948 \\
(0.00773)\end{array}$ \\
\hline B_Activity & $\begin{array}{c}0.0746 \\
(0.0473)\end{array}$ & $\begin{array}{c}0.00672^{* * * *} \\
(0.00194)\end{array}$ & $\begin{array}{c}0.00661^{* *} \\
(0.00299)\end{array}$ & $\begin{array}{c}0.00727^{* * * *} \\
(0.00206)\end{array}$ \\
\hline B_Women & $\begin{array}{l}0.0793 \text { * } \\
(0.0472)\end{array}$ & $\begin{array}{l}-0.00202 \\
(0.00190)\end{array}$ & $\begin{array}{l}-0.00125 \\
(0.00297)\end{array}$ & $\begin{array}{l}-0.00326 \\
(0.00200)\end{array}$ \\
\hline AC_Exp & $\begin{array}{l}0.0188 \\
-1.444\end{array}$ & $\begin{array}{l}-0.0130 \\
(0.0604)\end{array}$ & $\begin{array}{c}0.0507 \\
(0.0936)\end{array}$ & $\begin{array}{l}-0.0265 \\
(0.0649)\end{array}$ \\
\hline IENVPI & & $\begin{array}{l}0.334^{* * *} \\
(0.0550)\end{array}$ & $\begin{array}{l}0.679 * * * \\
(0.0997)\end{array}$ & $\begin{array}{l}0.157^{* * *} \\
(0.0489)\end{array}$ \\
\hline ERRI & $\begin{array}{c}1.146 \\
-9.001\end{array}$ & $\begin{array}{c}0.848^{* * *} \\
(0.160)\end{array}$ & $\begin{array}{c}1.280^{* * *} \\
(0.266)\end{array}$ & $\begin{array}{c}0.617^{* * *} \\
(0.145)\end{array}$ \\
\hline Civil_Law & & $\begin{array}{c}-0.0528 \\
(0.144)\end{array}$ & $\begin{array}{l}-0.189 \\
(0.253)\end{array}$ & $\begin{array}{c}-0.00231 \\
(0.128)\end{array}$ \\
\hline TranspIndex & & $\begin{array}{l}0.850^{* * * *} \\
(0.0611)\end{array}$ & $\begin{array}{c}1.765^{* * *} \\
(0.116)\end{array}$ & $\begin{array}{l}0.332 * * * \\
(0.0534)\end{array}$ \\
\hline LOIndex & & $\begin{array}{c}-0.327^{* * * *} \\
(0.0622)\end{array}$ & $\begin{array}{c}-0.410^{* * *} \\
(0.107)\end{array}$ & $\begin{array}{c}-0.256^{* * *} \\
(0.0556)\end{array}$ \\
\hline JEIndex & & $\begin{array}{c}-0.159 * * * \\
(0.0600)\end{array}$ & $\begin{array}{c}-0.357^{* * * *} \\
(0.107)\end{array}$ & $\begin{array}{l}-0.0603 \\
(0.0533)\end{array}$ \\
\hline Mandatory & & $\begin{array}{c}1.334^{* * *} \\
(0.345)\end{array}$ & $\begin{array}{c}2.255^{* * * *} \\
(0.608)\end{array}$ & $\begin{array}{l}0.698^{* *} \\
(0.310)\end{array}$ \\
\hline \multicolumn{5}{|c|}{ Zone, Industry and Year included } \\
\hline$R^{2}$ & $0.9067^{* * *}$ & & & \\
\hline $\begin{array}{l}\text { Log-Likelihood } \\
\text { LR test }\end{array}$ & & $\begin{array}{l}-7533.5816 \\
2873.07^{* * *}\end{array}$ & $\begin{array}{l}-3809.8896 \\
3730.89 * * *\end{array}$ & $\begin{array}{c}-5522.8182 \\
1568.36^{* * *}\end{array}$ \\
\hline
\end{tabular}


Additionally, in order to obtain robust results, we estimate Equation (1) again considering as dependent variables two subdivisions of the variable EnvI.Inf. The variable EnvI.Inf1 would identify the practices related to the level of integration of corporate information, taking into account the global activities of the firms, while the variable EnvI.Inf2 would represent the content of the report relative to the inclusion or not of the different GRI environmental indicators and crisis management systems or reputation disaster recovery plans.

The results reflected in the last two columns of Table 4 confirm the initial empirical evidence, although, according to the coefficients, the direct and indirect impact of environmental innovation is higher in the level of integration of the global activities of the companies than in the content disclosed. Thus, the direct impact of EnvInno on the EnvI.Inf1 variable is 0.556 and is 0.189 for EnvI.Inf2. The indirect impact that can be observed through the mediating factor, EnvPerf, is 0.00625 and 0.00569 , respectively.

Regarding the control variables, we observe that the largest and oldest companies are the most active in terms of environmental responsibility and transparency. Monitoring mechanisms associated with the activity of the board of directors or surveillance by analysts correct the opposition that powerful CEOs can exercise. Corporate transparency is negatively affected by problems of access to financing and the existence of traditional legal and judicial frameworks from an economic point of view. On the contrary, institutional environments, at both the national and sectorial levels, oriented towards environmental protection and corporate transparency with a more current conception favor corporate responsibility.

\subsection{Complementary Analysis}

The opposition of CEOs to the disclosure of integrated information according to the requirements of the IIRC—observed in studies such as those of García-Sánchez et al. (2020a) and the results obtained in the robust analyses pointing to a preference for the disclosure of integrated information vs. greater content by innovative companies-should make us think that perhaps companies have a certain aversion to the disclosure of certain information about their environmental strategy and activities, rather than to the integrated presentation of the same.

In this sense, various authors use terms such as Emergent Active Greening (Winn and Angell 2000) and Silent Green Firms (Delmas and Burbano 2011) to refer to companies that, with good environmental performance, avoid fully or partially communicating their environmental performance. Among the possible reasons for this strategic decision to remain silent, there seems to be a conviction that the most environmentally responsible companies would avoid disclosing information about all their responsible activities in order to avoid creating expectations among the different stakeholders that they later cannot reach, which would entail a risk of being accused of hypocrisy.

In this sense, our complementary analyses are aimed at analyzing whether the most environmentally innovative companies adopt these strategies in their corporate reports. To do this, following authors such as García-Sánchez et al. (2020b), we define the EnvGap variable, calculated using the standardized difference of the environmental performance and the environmental disclosure scores of Asset4 and Bloomberg. Later, we create a dummy variable that takes the value of 1 for those firms whose EnvGap is higher than 0 due to the companies having implemented more environmentally responsible policies and actions that they disclose in their reports. This procedure is used by Parra-Dominguez et al. (2021). In Table 5, it can be observed that the most innovative companies from the environmental point of view are very likely to adopt strategies of silence in their reports in relation to certain information on their environmental performance (EnvInno: Coeff. 2.128; $p$-value $=0.000)$. 
Table 5. Complementary model.

\begin{tabular}{|c|c|}
\hline & Dummy Silent Green Disclosures \\
\hline & $\begin{array}{c}\text { Coeff. } \\
\text { (Std. Error) }\end{array}$ \\
\hline EnvInno & $\begin{array}{c}2.128^{* * *} \\
(0.503)\end{array}$ \\
\hline F_Size & $\begin{array}{c}-0.435^{* * *} \\
(0.140)\end{array}$ \\
\hline F_Age & $\begin{array}{c}0.00432 \\
(0.00668)\end{array}$ \\
\hline ROA & $\begin{array}{l}-0.0132 \\
(0.0168)\end{array}$ \\
\hline Growth & $\begin{array}{l}0.0449 \\
(0.194)\end{array}$ \\
\hline Error & $\begin{array}{c}0.287 \\
(0.745)\end{array}$ \\
\hline KZIndex & $\begin{array}{c}9.993 \\
(24.28)\end{array}$ \\
\hline Leverage & $\begin{array}{l}-0.000124 \\
(0.000256)\end{array}$ \\
\hline WorCap & $\begin{array}{l}-8.74 \mathrm{e}-10 \\
(1.12 \mathrm{e}-09)\end{array}$ \\
\hline Divid & $\begin{array}{c}-0.000494 \\
(0.000708)\end{array}$ \\
\hline F_Intern & $\begin{array}{c}0.00771 \\
(0.00767)\end{array}$ \\
\hline Analysts & $\begin{array}{c}0.0507^{* *} \\
(0.0252)\end{array}$ \\
\hline CPI & $\begin{array}{c}-0.414^{*} \\
(0.236)\end{array}$ \\
\hline B_Size & $\begin{array}{c}0.0104 \\
(0.0570)\end{array}$ \\
\hline B_Activity & $\begin{array}{c}0.0202 \\
(0.0156)\end{array}$ \\
\hline B_Women & $\begin{array}{l}0.00207 \\
(0.0154)\end{array}$ \\
\hline AC_Exp & $\begin{array}{l}0.869 * \\
(0.448)\end{array}$ \\
\hline IENVPI & $\begin{array}{c}0.402 \\
(0.309)\end{array}$ \\
\hline ERRI & $\begin{array}{l}1.254 \\
(0.927)\end{array}$ \\
\hline Civil_Law & $\begin{array}{l}-1.576^{* *} \\
(0.733)\end{array}$ \\
\hline TranspIndex & $\begin{array}{c}-0.730^{* *} \\
(0.333)\end{array}$ \\
\hline LOIndex & $\begin{array}{l}-0.220 \\
(0.343)\end{array}$ \\
\hline JEIndex & $\begin{array}{l}-0.439 \\
(0.302)\end{array}$ \\
\hline Mandatory & $\begin{array}{c}-2.937^{* *} \\
-1.408\end{array}$ \\
\hline \multicolumn{2}{|c|}{ Zone, Industry and Year included } \\
\hline $\begin{array}{l}\text { Log-Likelihood } \\
\text { LR test }\end{array}$ & $\begin{array}{c}-305.85377 \\
49.80^{* * *}\end{array}$ \\
\hline
\end{tabular}

\section{Conclusions}

This study aimed to analyze the impact of environmental innovation on the level of integrated environmental information disclosed by companies and to examine the 
mediating role of environmental performance in this relationship. The results of this research indicate that innovative companies are in favor of issuing integrated information in relation to their environmental strategies, actions and risks at a global level, although the information reported is selective and would not allow a faithful understanding of the environmental commitments of the companies.

This work has important implications for the academy and business professions. Theoretically, this study, firstly, contributes to the knowledge of the determinants of environmental disclosure, showing a clear positive effect of environmental innovation on the level of integrated environmental disclosure. Secondly, it opens the black box involving the relationship between environmental innovation and integrated environmental disclosure by showing the mediating role of environmental performance. Finally, this study extends the field of application of voluntary disclosure theory, which is still little used to explain the dynamics related to environmental disclosure.

From a practical point of view, our evidence shows the existence of silence strategies regarding the informative content of corporate reports, which makes it difficult for different stakeholders to make decisions. Despite the fact that the need to establish the mandatory use of standardized models in the disclosure of non-financial information seems appropriate, it should be borne in mind that these decisions are designed to prevent the most environmentally responsible companies from being negatively affected by incorrect extrapolations of the evolution of the company that may come from different groups. These adverse effects would cause proprietary costs higher than the economic benefits that the company could obtain from disclosures more appropriate to its business reality.

Nevertheless, this study is not without limitations. A first limitation is related to the use of aggregate indicators to measure corporate transparency. These indicators, while having the advantage of objectivity in the measurement, do not allow an in-depth analysis of individual topics and therefore do not allow for the identification of the issues most dealt with by companies within the disclosure. A second limitation is linked to the selection of the sample. This study focuses on the largest companies listed worldwide. This could create problems in the generalization of the results. In particular, it could be problematic to extend the results obtained also to small and medium-sized enterprises.

However, these limitations do not affect the overall quality of the work and, above all, provide important insights for future research. Thus, with regard to the first limitation, future research, through the use of different measures to compute corporate transparency, will be able to analyze the less disclosed topics by the companies that are most committed to the environment. In relation to the second limitation, future research will be able to replicate this study on a different sample represented by international small and mediumsized enterprises. Furthermore, a future study may be carried out in order to examine the role of other mediating or moderating variables in the relationship between environmental innovation and integrated environmental information.

Author Contributions: Conceptualization, I.-M.G.-S., N.R. and F.V.; methodology, I.-M.G.-S.; validation, I.-M.G.-S., N.R. and F.V.; investigation, N.R.; resources, I.-M.G.-S.; data curation, I.-M.G.-S.; writing-original draft preparation, I.-M.G.-S., N.R. and F.V.; writing—review and editing, I.-M.G.-S., N.R. and F.V.; visualization, I.-M.G.-S. and F.V.; supervision, I.-M.G.S. and F.V.; project administration, I.-M.G.-S. and F.V. All authors haveread and agreed to the published version of the manuscript.

Funding: Consejeria de Educacion, Junta de Castilla y León [Grant/Award No. SA069G18]; Ministerio de Ciencia e Innovacion [Grant/ Award No. ECO2013-43838P]; Ministerio de Ciencia, Innovación y Universidades [Grant/Award No. RTI2018-093423-B-I00]; and Universidad de Salamanca [Grant/Award No. USAL2017-DISAQ] Junta de Castilla y León y Fondo Europeo de Desarrollo Regional [Grant/Award No. CLU-2019-03 Unidad de Excelencia “Gestión Económica para la Sostenibilidad" (GECOS)].

Data Availability Statement: Not applicable.

Conflicts of Interest: The authors declare no conflict of interest. 


\section{References}

Alazzani, Abdulsamad, and Wan Nordin Wan-Hussin. 2013. Global Reporting Initiative's environmental reporting: A study of oil and gas companies. Ecological Indicators 32: 19-24. [CrossRef]

Albino, Vito, Azzurra Balice, and Rosa Maria Dangelico. 2009. Environmental strategies and green product development: An overview on sustainability-driven companies. Business Strategy and the Environment 18: 83-96. [CrossRef]

Al-Tuwaijri, Sulaiman A., Theodore E. Christensen, and K. E. Hughes II. 2004. The relations among environmental disclosure, environmental performance, and economic performance: A simultaneous equations approach. Accounting, Organizations and Society 29: 447-71. [CrossRef]

Ambec, Stefan, and Paul Lanoie. 2008. Does it pay to be green? A systematic overview. The Academy of Management Perspectives 22: 45-62.

Amorelli, María-Florencia, and Isabel-María García-Sánchez. 2020. Trends in the dynamic evolution of board gender diversity and corporate social responsibility. Corporate Social Responsibility and Environmental Management 28: 537-54. [CrossRef]

Amor-Esteban, Victor, María Purificación Galindo-Villardón, and Isabel-María García-Sánchez. 2018. Useful information for stakeholder engagement: A multivariate proposal of an Industrial Corporate Social Responsibility Practices Index. Sustainable Development 26: 620-37. [CrossRef]

Amor-Esteban, Victor, María Purificación Galindo-Villardón, Isabel-María García-Sánchez, and Fátima David. 2019. An extension of the industrial corporate social responsibility practices index: New information for stakeholder engagement under a multivariate approach. Corporate Social Responsibility and Environmental Management 26: 127-40. [CrossRef]

Baalouch, Fatma, Salma Damak Ayadi, and Khaled Hussainey. 2019. A study of the determinants of environmental disclosure quality: Evidence from French listed companies. Journal of Management and Governance 23: 939-971. [CrossRef]

Bennett, Martin, and Peter James. 1998. The Green Bottom Line: Current Practice and Future Trends in Environmental Management Accounting. Sheffield: Greenleaf Publishing.

Bewley, Kathryn, and Yue Li. 2000. Disclosure of environmental information by Canadian manufacturing companies: A voluntary disclosure perspective. In Advances in Environmental Accounting \& Management. Bingley: Emerald Group Publishing Limited, pp. 201-26.

Blättel-Mink, Birgit. 1998. Innovation towards sustainable economy-the integration of economy and ecology in companies. Sustainable Development 6: 49-58. [CrossRef]

Brammer, Stephen, and Stephen Pavelin. 2008. Factors influencing the quality of corporate environmental disclosure. Business Strategy and the Environment 17: 120-36. [CrossRef]

Buniamin, Sharifah. 2010. The quantity and quality of environmental reporting in annual report of public listed companies in Malaysia. Issues in Social and Environmental Accounting 4: 115-35. [CrossRef]

Burritt, Roger L. 2002. Environmental reporting in Australia: Current practices and issues for the future. Business Strategy and the Environment 11: 391-406. [CrossRef]

Carrión-Flores, Carmen E., and Robert Innes. 2010. Environmental innovation and environmental performance. Journal of Environmental Economics and Management 59: 27-42. [CrossRef]

Cecere, Grazia, Nicoletta Corrocher, Cédric Gossart, and Muge Ozman. 2014. Lock-in and path dependence: An evolutionary approach to eco-innovations. Journal of Evolutionary Economics 24: 1037-65. [CrossRef]

Chen, Yu-Shan. 2008. The driver of green innovation and green image-green core competence. Journal of Business Ethics 81: 531-43. [CrossRef]

Chiou, Tzu-Yun, Hing Kai Chan, Fiona Lettice, and Sai Ho Chung. 2011. The influence of greening the suppliers and green innovation on environmental performance and competitive advantage in Taiwan. Transportation Research Part E: Logistics and Transportation Review 47: 822-36. [CrossRef]

Clarkson, Peter M., Yue Li, Gordon D. Richardson, and Florin P. Vasvari. 2008. Revisiting the relation between environmental performance and environmental disclosure: An empirical analysis. Accounting, Organizations and Society 33: 303-27. [CrossRef]

Cormier, Denis, Michel Magnan, and Barbara Van Velthoven. 2005. Environmental disclosure quality in large German companies: Economic incentives, public pressures or institutional conditions? European Accounting Review 14: 3-39. [CrossRef]

Dawkins, Cedric E., and John W. Fraas. 2011. Erratum to: Beyond acclamations and excuses: Environmental performance, voluntary environmental disclosure and the role of visibility. Journal of Business Ethics 99: 383-97. [CrossRef]

Del Río, Pablo, Javier Carrillo-Hermosilla, and Totti Könnölä. 2010. Policy strategies to promote eco-innovation: An integrated framework. Journal of Industrial Ecology 14: 541-57. [CrossRef]

Delmas, Magali A., and Vanessa Cuerel Burbano. 2011. The drivers of greenwashing. California Management Review 54: 64-87. [CrossRef]

Dye, Ronald A. 1985. Disclosure of nonproprietary information. Journal of Accounting Research 23: 123-45. [CrossRef]

Dye, Ronald A. 2001. An evaluation of "essays on disclosure" and the disclosure literature in accounting. Journal of Accounting and Economics 32: 181-235. [CrossRef]

Dyllick, Thomas, and Kai Hockerts. 2002. Beyond the business case for corporate sustainability. Business Strategy and the Environment 11: 130-41. [CrossRef] 
Eco-Innovation Observatory. 2016. Policies and Practices for Eco-Innovation Up-Take and Circular Economy Transition. Available online: https:/ / ec.europa.eu/environment/ecoap/policies-and-practices-eco-innovation-uptake-and-circular-economytransition_en (accessed on 15 February 2021).

Eiadat, Yousef, Aidan Kelly, Frank Roche, and Hussein Eyadat. 2008. Green and competitive? An empirical test of the mediating role of environmental innovation strategy. Journal of World Business 43: 131-45. [CrossRef]

Epstein, Marc J., and Martin Freedman. 1994. Social disclosure and the individual investor. Accounting, Auditing E Accountability Journal 7: 94-109.

Esty, Daniel C., and Micheal E. Porter. 2001. Ranking national environmental regulation and performance: A leading indicator of future competitiveness? The Global Competitiveness Report 2002: 78-100.

Esty, Daniel C., and Andrew Winston. 2009. Green to Gold: How Smart Companies Use Environmental Strategy to Innovate, Create Value, and Build Competitive Advantage. Hoboken: John Wiley \& Sons.

Flammer, Caroline. 2013. Corporate social responsibility and shareholder reaction: The environmental awareness of investors. Academy of Management Journal 56: 758-81. [CrossRef]

Fondevila, Miguel Marco, José M. Moneva, and Sabina Scarpellini. 2019. Environmental disclosure and Eco-innovation interrelation. The case of Spanish firms. Revista de Contabilidad-Spanish Accounting Review 22: 73-87.

Forsman, Helena. 2013. Environmental innovations as a source of competitive advantage or vice versa? Business Strategy and the Environment 22: 306-20. [CrossRef]

Frías-Aceituno, José-Valeriano, and Beatriz Aibar-Gúzman. 2021. Is It Necessary to Centralize Power in The CEO To Ensure Environmental Innovation? Administrative Sciences. forthcoming.

Frías-Aceituno, José-Valeriano, Lázaro Rodríguez-Ariza, and Isabel-María García-Sánchez. 2013a. Is integrated reporting determined by a country's legal system? An exploratory study. Journal of Cleaner Production 44: 45-55. [CrossRef]

Frías-Aceituno, José-Valeriano, Lázaro Rodriguez-Ariza, and Isabel-María García-Sánchez. 2013b. The role of the board in the dissemination of integrated corporate social reporting. Corporate Social Responsibility and Environmental Management 20: 219-33. [CrossRef]

Frías-Aceituno, José-Valeriano, Lázaro Rodríguez-Ariza, and Isabel-María García-Sánchez. 2014. Explanatory factors of integrated sustainability and financial reporting. Business Strategy and the Environment 23: 56-72. [CrossRef]

Frondel, Manuel, Jens Horbach, and Klaus Rennings. 2007. End-of-pipe or cleaner production? An empirical comparison of environmental innovation decisions across OECD countries. Business Strategy and the Environment 16: 571-84. [CrossRef]

Frondel, Manuel, Jens Horbach, and Klaus Rennings. 2008. What triggers environmental management and innovation? Empirical evidence for Germany. Ecological Economics 66: 153-60. [CrossRef]

Garcés-Ayerbe, Concepción, Sabina Scarpellini, Jesus Valero-Gil, and Pilar Rivera-Torres. 2016. Proactive environmental strategy development: From laggard to eco-innovative firms. Journal of Organizational Change Management 29: 1118-34. [CrossRef]

García-Sánchez, Isabel-María, and Ligia Noguera-Gámez. 2017a. Integrated reporting and stakeholder engagement: The effect on information asymmetry. Corporate Social Responsibility and Environmental Management 24: 395-413. [CrossRef]

García-Sánchez, Isabel-María, and Ligia Noguera-Gámez. 2017b. Integrated information and the cost of capital. International Business Review 26: 959-75. [CrossRef]

García-Sánchez, Isabel-María, and Ligia Noguera-Gámez. 2018. Institutional investor protection pressures versus firm incentives in the disclosure of integrated reporting. Australian Accounting Review 28: 199-219. [CrossRef]

García-Sánchez, Isabel-María, Lázaro Rodríguez-Ariza, and José-Valeriano Frías-Aceituno. 2013. The cultural system and integrated reporting. International Business Review 22: 828-38. [CrossRef]

García-Sánchez, Isabel-María, Jennifer Martínez-Ferrero, and María Antonia García-Benau. 2019. Integrated reporting: The mediating role of the board of directors and investor protection on managerial discretion in munificent environments. Corporate Social Responsibility and Environmental Management 26: 29-45. [CrossRef]

García-Sánchez, Isabel-María, Nicola Raimo, and Filippo Vitolla. 2020a. CEO power and integrated reporting. Meditari Accountancy Research. [CrossRef]

García-Sánchez, Isabel-María, Nazim Hussain, Sana-Akbar Khan, and Jennifer Martínez-Ferrero. 2020b. Do Markets Punish or Reward Corporate Social Responsibility Decoupling? Business \& Society. [CrossRef]

García-Sánchez, Isabel-María, Cristina Aibar-Guzmán, and Beatriz Aibar-Guzmán. 2020c. The effect of institutional ownership and ownership dispersion on eco-innovation. Technological Forecasting and Social Change 1158: 120173. [CrossRef]

García-Sánchez, Isabel-María, Isabel Gallego-Álvarez, and José-Luis Zafra-Gómez. 2020d. Do the ecoinnovation and ecodesign strategies generate value added in munificent environments? Business Strategy and the Environment 29: 1021-33. [CrossRef]

García-Sánchez, Isabel-María, Beatriz Aibar-Guzmán, Cristina Aibar-Guzmán, and Tânia-Cristina Azevedo. 2020e. CEO ability and sustainability disclosures: The mediating effect of corporate social responsibility performance. Corporate Social Responsibility and Environmental Management 27: 1565-77. [CrossRef]

García-Sánchez, Isabel-María, Nicola Raimo, Arcangelo Marrone, and Filippo Vitolla. 2020f. How does integrated reporting change in light of COVID-19? A Revisiting of the content of the integrated reports. Sustainability 12: 7605. [CrossRef]

García-Sánchez, Isabel-María, Lázaro Rodríguez-Ariza, and María-del-Carmen Granada-Abarzuza. 2021. The Influence of Female Directors and Institutional Pressures on Corporate Social Responsibility in Family Firms in Latin America. Journal of Risk and Financial Management 14: 28. [CrossRef] 
Giannarakis, Grigoris, George Konteos, Nikolaos Sariannidis, and George Chaitidis. 2017. The relation between voluntary carbon disclosure and environmental performance: The case of S\&P 500. International Journal of Law and Management 59: 784-803.

Giannarakis, Grigoris, Andreas Andronikidis, and Nikolaos Sariannidis. 2019. Determinants of environmental disclosure: Investigating new and conventional corporate governance characteristics. Annals of Operations Research 294: 87-105. [CrossRef]

Healy, Paul M., and Krishna G. Palepu. 2001. Information asymmetry, corporate disclosure, and the capital markets: A review of the empirical disclosure literature. Journal of Accounting and Economics 31: 405-40. [CrossRef]

Herremans, Irene M., Parporn Akathaporn, and Morris McInnes. 1993. An investigation of corporate social responsibility reputation and economic performance. Accounting, Organizations and Society 18: 587-604. [CrossRef]

Ho, Elaine, Sondra Eger, and Simon C. Courtenay. 2018. Assessing current monitoring indicators and reporting for cumulative effects integration: A case study in Muskoka, Ontario, Canada. Ecological Indicators 95: 862-76. [CrossRef]

Hojnik, Jana, and Mitja Ruzzier. 2016. What drives eco-innovation? A review of an emerging literature. Environmental Innovation and Societal Transitions 19: 31-41. [CrossRef]

Huang, Rongbing, and Danping Chen. 2015. Does environmental information disclosure benefit waste discharge reduction? Evidence from China. Journal of Business Ethics 129: 535-52. [CrossRef]

Huang, Cheng-Li, and Fan-Hua Kung. 2010. Drivers of environmental disclosure and stakeholder expectation: Evidence from Taiwan. Journal of Business Ethics 96: 435-51. [CrossRef]

Jitmaneeroj, Boonlert. 2016. Reform priorities for corporate sustainability. Management Decision 54: 1497-521. [CrossRef]

Junior, Flavio Hourneaux, Barbara Galleli, Dolores Gallardo-Vázquez, and Maria Isabel Sánchez-Hernández. 2017. Strategic aspects in sustainability reporting in oil \& gas industry: The comparative case-study of Brazilian Petrobras and Spanish Repsol. Ecological Indicators 72: 203-14.

Kaplan, Steven N., and Luigi Zingales. 1997. Do investment-cash flow sensitivities provide useful measures of financing constraints? The Quarterly Journal of Economics 112: 169-215. [CrossRef]

Kemp, René, and Vanessa Oltra. 2011. Research insights and challenges on eco-innovation dynamics. Industry and Innovation 18: 249-53. [CrossRef]

Kemp, René, and Peter Pearson. 2007. Final Report MEI Project about Measuring Eco-Innovation. Maastricht: UM Merit, vol. 10.

Kemp, René, and Serena Pontoglio. 2011. The innovation effects of environmental policy instruments-A typical case of the blind men and the elephant? Ecological Economics 72: 28-36. [CrossRef]

Konadu, Renata, Samuel Owusu-Agyei, Theophilus A. Lartey, Albert Danso, Samuel Adomako, and Joseph Amankwah-Amoah. 2020. CEOs' reputation, quality management and environmental innovation: The roles of stakeholder pressure and resource commitment. Business Strategy and the Environment 29: 2310-23. [CrossRef]

Kuo, Lopin, and Vivian Yi-Ju Chen. 2013. Is environmental disclosure an effective strategy on establishment of environmental legitimacy for organization? Management Decision 51: 1462-87. [CrossRef]

La Porta, Rafael, Florencio Lopez-de-Silanes, Andrei Shleifer, and Robert W. Vishny. 1998. Law and finance. Journal of Political Economy 106: 1113-55. [CrossRef]

Lee, Ki-Hoon, and Byung Min. 2015. Green R\&D for eco-innovation and its impact on carbon emissions and firm performance. Journal of Cleaner Production 108: 534-42.

Li, Yue, Gordon D. Richardson, and Daniel B. Thornton. 1997. Corporate disclosure of environmental liability information: Theory and evidence. Contemporary Accounting Research 14: 435-74. [CrossRef]

Liao, Zhongju. 2016. Temporal cognition, environmental innovation, and the competitive advantage of enterprises. Journal of Cleaner Production 135: 1045-53. [CrossRef]

Long, Xingle, Yaqiong Chen, Jianguo Du, Keunyeob Oh, and Insoo Han. 2017. Environmental innovation and its impact on economic and environmental performance: Evidence from Korean-owned firms in China. Energy Policy 107: 131-37. [CrossRef]

Luo, Le, and Qingliang Tang. 2014. Does voluntary carbon disclosure reflect underlying carbon performance? Journal of Contemporary Accounting E Economics 10: 191-205.

Martínez-Ferrero, Jennifer, David Ruiz-Cano, and Isabel-María García-Sánchez. 2016. The causal link between sustainable disclosure and information asymmetry: The moderating role of the stakeholder protection context. Corporate Social Responsibility and Environmental Management 23: 319-32. [CrossRef]

Mirata, Murat, and Tareq Emtairah. 2005. Industrial symbiosis networks and the contribution to environmental innovation: The case of the Landskrona industrial symbiosis programme. Journal of Cleaner Production 13: 993-1002. [CrossRef]

Nyquist, Siv. 2003. The legislation of environmental disclosures in three Nordic countries-A comparison. Business Strategy and the Environment 12: 12-25. [CrossRef]

O'Dwyer, Brendan. 2003. The ponderous evolution of corporate environmental reporting in Ireland. Recent evidence from publicly listed companies. Corporate Social Responsibility and Environmental Management 10: 91-100. [CrossRef]

Odoemelam, Ndubuisi, and Regina G. Okafor. 2018. The influence of corporate governance on environmental disclosure of listed non-financial firms in Nigeria. Indonesian Journal of Sustainability Accounting and Management 2: 25-49. [CrossRef]

Oltra, Vanessa, and Maïder Saint Jean. 2005. The dynamics of environmental innovations: Three stylised trajectories of clean technology. Economics of Innovation and New Technology 14: 189-212. [CrossRef]

Parra-Domínguez, Javier, Fátima David, and Tânia-Cristina Azevedo. 2021. Family firms and coupling among CSR disclosures and performance. Administrative Sciences. forthcoming. 
Porter, Micheal E., and Claas van der Linde. 1995. Toward a new conception of the environment-competitiveness relationship. Journal of Economic Perspectives 9: 97-118. [CrossRef]

Qiu, Lu, Xiaowen Jie, Yanan Wang, and Minjuan Zhao. 2020. Green product innovation, green dynamic capability, and competitive advantage: Evidence from Chinese manufacturing enterprises. Corporate Social Responsibility and Environmental Management 27: 146-65. [CrossRef]

Radu, Camélia, and Claude Francoeur. 2017. Does innovation drive environmental disclosure? A new insight into sustainable development. Business Strategy and the Environment 26: 893-911. [CrossRef]

Raimo, Nicola, Marianna Zito, and Alessandra Caragnano. 2019. Does national culture affect integrated reporting quality? A focus on GLOBE dimensions. Paper presented at 9th International Symposium on Natural Resources Management, Zaječar, Serbia, May 31; pp. 383-392.

Raimo, Nicola, Elbano de Nuccio, Anastasia Giakoumelou, Felice Petruzzella, and Filippo Vitolla. 2020a. Non-financial information and cost of equity capital: An empirical analysis in the food and beverage industry. British Food Journal 123: 49-65. [CrossRef]

Raimo, Nicola, Alessandra Ricciardelli, Michele Rubino, and Filippo Vitolla. 2020b. Factors affecting human capital disclosure in an integrated reporting perspective. Measuring Business Excellence 24: 575-92. [CrossRef]

Raimo, Nicola, Filippo Vitolla, Arcangelo Marrone, and Michele Rubino. 2020c. The role of ownership structure in integrated reporting policies. Business Strategy and the Environment 29: 2238-50. [CrossRef]

Raimo, Nicola, Alessandra Caragnano, Marianna Zito, Filippo Vitolla, and Massimo Mariani. 2021a. Extending the benefits of ESG disclosure: The effect on the cost of debt financing. Corporate Social Responsibility and Environmental Management. [CrossRef]

Raimo, Nicola, Filippo Vitolla, Arcangelo Marrone, and Michele Rubino. 2021b. Do audit committee attributes influence integrated reporting quality? An agency theory viewpoint. Business Strategy and the Environment 30: 522-34. [CrossRef]

Rao, Kathyayini Kathy, Carol A. Tilt, and Laurence H. Lester. 2012. Corporate governance and environmental reporting: An Australian study. Corporate Governance: The International Journal of Business in Society 12: 143-63.

Rennie, Susannah C. 2016. Providing information on environmental change: Data management, discovery and access in the UK Environmental Change Network Data Centre. Ecological Indicators 68: 13-20. [CrossRef]

Salvi, Antonio, Filippo Vitolla, Nicola Raimo, Michele Rubino, and Felice Petruzzella. 2020a. Does intellectual capital disclosure affect the cost of equity capital? An empirical analysis in the integrated reporting context. Journal of Intellectual Capital 21: 985-1007. [CrossRef]

Salvi, Antonio, Filippo Vitolla, Anastasia Giakoumelou, Nicola Raimo, and Michele Rubino. 2020b. Intellectual capital disclosure in integrated reports: The effect on firm value. Technological Forecasting and Social Change 160: 120228. [CrossRef]

Scarpellini, Sabina, Alfonso Aranda, Juan Aranda, Eva Llera, and Miguel Marco. 2012. R\&D and eco-innovation: Opportunities for closer collaboration between universities and companies through technology centers. Clean Technologies and Environmental Policy 14: 1047-58.

Sharif, Mehmoona, and Kashif Rashid. 2014. Corporate governance and corporate social responsibility (CSR) reporting: An empirical evidence from commercial banks (CB) of Pakistan. Quality \& Quantity 48: 2501-21.

Singhvi, Surendra S., and Harsha B. Desai. 1971. An empirical analysis of the quality of corporate financial disclosure. The Accounting Review 46: 129-38.

Skordoulis, Michalis, Stamatios Ntanos, Grigorios L. Kyriakopoulos, Garyfallos Arabatzis, Spyros Galatsidas, and Miltiadis Chalikias. 2020. Environmental Innovation, Open Innovation Dynamics and Competitive Advantage of Medium and Large-Sized Firms. Journal of Open Innovation: Technology, Market, and Complexity 6: 195. [CrossRef]

Trireksani, Terri, and Hadrian Geri Djajadikerta. 2016. Corporate governance and environmental disclosure in the Indonesian mining industry. Australasian Accounting, Business and Finance Journal 10: 18-28. [CrossRef]

Verrecchia, Robert E. 1983. Discretionary disclosure. Journal of Accounting and Economics 5: 179-94. [CrossRef]

Vitolla, Filippo, and Nicola Raimo. 2018. Adoption of integrated reporting: Reasons and benefits-A case study analysis. International Journal of Business and Management 13: 244-50. [CrossRef]

Vitolla, Filippo, Nicola Raimo, and Elbano De Nuccio. 2018. Integrated reporting: Development and state of art-The Italian case in the international context. International Journal of Business and Management 13: 233-40. [CrossRef]

Vitolla, Filippo, Nicola Raimo, and Michele Rubino. 2019a. Appreciations, criticisms, determinants, and effects of integrated reporting: A systematic literature review. Corporate Social Responsibility and Environmental Management 26: 518-28. [CrossRef]

Vitolla, Filippo, Nicola Raimo, Michele Rubino, and Antonello Garzoni. 2019b. How pressure from stakeholders affects integrated reporting quality. Corporate Social Responsibility and Environmental Management 26: 1591-606. [CrossRef]

Vitolla, Filippo, Nicola Raimo, Michele Rubino, and Antonello Garzoni. 2019c. The impact of national culture on integrated reporting quality. A stakeholder theory approach. Business Strategy and the Environment 28: 1558-71. [CrossRef]

Vitolla, Filippo, Nicola Raimo, and Michele Rubino. 2020a. Board characteristics and integrated reporting quality: An agency theory perspective. Corporate Social Responsibility and Environmental Management 27: 1152-63. [CrossRef]

Vitolla, Filippo, Nicola Raimo, Arcangelo Marrone, and Michele Rubino. 2020b. The role of board of directors in intellectual capital disclosure after the advent of integrated reporting. Corporate Social Responsibility and Environmental Management 27: $2188-200$. [CrossRef]

Vitolla, Filippo, Nicola Raimo, Michele Rubino, and Antonello Garzoni. 2020c. The determinants of integrated reporting quality in financial institutions. Corporate Governance: The International Journal of Business in Society 20: 429-44. [CrossRef] 
Vitolla, Filippo, Nicola Raimo, Michele Rubino, and Giovanni Maria Garegnani. 2021a. Do cultural differences impact ethical issues? Exploring the relationship between national culture and quality of code of ethics. Journal of International Management 27 : 100823. [CrossRef]

Vitolla, Filippo, Nicola Raimo, Michele Rubino, and Antonello Garzoni. 2021b. Broadening the horizons of intellectual capital disclosure to the sports industry: Evidence from top UEFA clubs. Meditari Accountancy Research. [CrossRef]

Vormedal, Irja, and Audun Ruud. 2009. Sustainability reporting in Norway-An assessment of performance in the context of legal demands and socio-political drivers. Business Strategy and the Environment 18: 207-22. [CrossRef]

Winn, Monica L., and Linda C. Angell. 2000. Towards a process model of corporate greening. Organization Studies 21: 1119-47. [CrossRef]

World Economic Forum. 2020. The Global Risks Report 2020. Available online: http://www3.weforum.org/docs/WEF_Global_Risk_ Report_2020.pdf (accessed on 10 January 2021).

Yin, Jianhua, and Sen Wang. 2018. The effects of corporate environmental disclosure on environmental innovation from stakeholder perspectives. Applied Economics 50: 905-19. [CrossRef]

Zhang, Yue-Jun, Yu-Lu Peng, Chao-Qun Ma, and Bo Shen. 2017. Can environmental innovation facilitate carbon emissions reduction? Evidence from China. Energy Policy 100: 18-28. [CrossRef] 